\title{
PENGARUH SUBSTITUSI DEDAK HALUS DENGAN TEPUNG KULIT KOPI DALAM RANSUM TERHADAP PERFORMA BROILER
}

\author{
Sandro Murib, M. Najoan. ${ }^{*)}$, Betty Bagau., ${ }^{*)}$ Ivonne M. Untu ${ }^{*}$
}

Fakultas Peternakan Universitas Sam RatulangiManado, 95115

\begin{abstract}
ABSTRAK
Upaya pencarian bahan baku pakan alternatif terus dilakukan selain dengan tujuan variasi pakan penyusun ransum juga dalam rangka menanggulangi kelangkaan bahan baku konvensional. Aneka bahan atau limbah produk pertanian belum dimanfaatkan secara maksimal, sekalipun segi ketersediaannya cukup melimpah, salah satu diantaranya adalah limbah kulit kopi. Suatu penelitian yang bertujuan untuk melihat Pengaruh Substitusi Dedak Halus dengan Tepung Kulit Kopi Dalam Ransum Terhadap Performa Broiler, telah dilaksanakan di kandang unggas Fakultas Peternakan UNSRAT Manado, selama 5 minggu menggunakan 60 ekor broiler strain CP 707. Metode penelitian yang digunakan adalah Rancangan Acak Lengkap yang terdiri dari 4 perlakuan dan 5 ulangan, dimana $\mathrm{R}_{0}=$ Penggantian dedak halus $0 \%$ ) atau ransum dengan dedak padi $21 \%+0 \%$ kulit kopi $; \mathrm{R}_{1}=$ Penggantian Dedak halus $(33.33 \%)$ atau ransum dengan dedak padi $14 \%+7 \%$ kulit kopi; $\mathrm{R}_{2}=$ Penggantian Dedak halus $(66.66 \%)$ atau ransum dengan dedak padi $7 \%+14$ $\%$ kulit kopi; $\mathrm{R}_{3}=$ Penggantian Dedak halus $(100 \%)$ atau ransum dengan dedak padi $0 \%+21 \%$ kulit kopi.Hasil yang diperoleh menunjukkan bahwa perlakuan memberikan pengaruh yang nyata $(\mathrm{P}<$ 0.05) terhadap konsumsi, pertambahan berat badan dan koversi ransum
\end{abstract}

*Korespondensi (corresponding Author) Email:sandromurib@gmail.com
Hasil uji BNJ menunjukkan bahwa semakin tinggi proporsi kulit kopi dalam ransum menyebabkan konsumsi dan pertambahan berat badan semakin menurun, sedangkan nilai konversi pada $\mathrm{R}_{3}$ nyata lebih tinggi di banding dengan $\mathrm{R}_{0}, \mathrm{R}_{1}$ dan $\mathrm{R}_{2}$.

Berdasarkan nilai konversi ransum hasil penelitian ini dapat disimpulkan bahwa tepung kulit kopi dapat menggantikan dedak halus sampai $66.66 \%$ atau penggunaannya sebesar $14 \%$ dalam ransum broiler.

Kata kunci :Broiler, Dedak Halus, Kulit Kopi , Performa broiler

\section{ABSTRACT}

THE EFFECTS OF SUBSTITUTION OF RICE BRAN AND COFFEE HULL MEAL IN RATION ON BROILER PERFORMANCE The effects of looking for alternative feed to variate feed ingredients for ration formulation is steel on going. The utilization of agricultural waste products are not maximized yet, although its availability are abundant, one of these agricultural waste products is coffee hull. The research evaluation the effects of rice bran and coffee hull meal in ration on broiler performances has been conducted at Faculty of Animal Science Unsrat Manado for six weeks using 60 broiler strain CP 707. Completely 
Randomized Design with 4 treatments and 5 replication was used. The treatments were $: \mathrm{R}_{0}=$ substitution of rice bran $(0 \%)$ or ration with $21 \%$ rice bran $+0 \%$ coffee hulls ; $\mathrm{R}_{1}=$ substitution of rice bran $(33.33 \%)$ or ration with $14 \%$ or ration with $+7 \%$ coffee hulls; $\mathrm{R}_{2}=$ substitution of rice bran $(66.66 \%)$ or ration with $7 \%+$ $14 \%$ coffee huls; $\mathrm{R}_{3}=$ substitution of rice bran $(100 \%)$ or ration with0 \% rice bran $+21 \%$ coffee hulls. The results showed that there were significant, effects of treatments on feed consumption, body gain and feed conversion. Tukey test showed that the higher proportion of coffee hull meal the lower feed consumption and body gain, on the other land feed conversion of $\mathrm{R}_{3}$ significantly higher compared to $\mathrm{R}_{0}$, $\mathrm{R}_{1}$ and $\mathrm{R}_{3}$.

Based on feed conversion it can be concluded that rice bran can be substituted by coffee hulls meal up to $66.66 \%$ or its utilization up to $14 \%$ in the broiler ration.

Key words :Broiler, Rice Bran, Coffee Hull, Performance broiler.

\section{PENDAHULUAN}

Kemajuan ilmu pengetahuan dan teknologi diiringi pula dengan meningkatnya pengetahuan akan kesehatan dan kebutuhan gizi masyarakat. Hal ini membuat masyarakat semakin selektif dalam hal memilih bahan makanan yang akan dikonsumsi dalam menu sehari-hari dan kesadaran akan pentingnya bahan makanan sumber protein hewani. Daging ayam masih merupakan favorit masyarakat dalam memenuhi kebutuhan protein hewani, oleh sebab itu memproduksi broiler dalam jumlah yang banyak dan terjamin kualitasnya masih sangat perlu dilakukan.

Keberhasilan usaha pemeliharaan ternak broiler sangat ditentukan oleh tersedianya bahan baku penyusun ransum yang memiliki kualitas yang cukup untuk pertumbuhan ternak. Upaya pencarian bahan baku pakan alternatif terus dilakukan selain dengan tujuan variasi pakan penyusun ransum juga dalam rangka menanggulangi kelangkaan bahan baku konvensional. Aneka bahan atau limbah produk pertanian belum dimanfaatkan secara maksimal, sekalipun segi ketersediaannya cukup melimpah, salah satu diantaranya adalah limbah kulit kopi.Produksi buah kopi Indonesia untuk tahun 2012 yaitu sedikitnya 748 ribu ton (Kementrian Perindustrian, 2013).

Kulit buah kopi merupakan produk samping dari pengolahan buah kopi yang jika tidak ditangani lebih lanjut akan menimbulkan pencemaran dan hingga saat ini belum dimanfaatkan dengan baik (Diniyah, N, dkk., 2013; Raudah dan Ernawati, 2012). Sebagai bahan limbah kulit kopi cukup mengandung zat-zat makanan yang dibutuhkan oleh ternak yang dapat dimanfaatkan sebagai salah satu bahan baku penyusun ransum ternak. Kandungan protein kulit buah kopi 
berkisar $11.18 \%$, serat kasarnya cukup tinggi yaitu dapat mencapai $21.74 \%$ dan nilai energi metabolisnya $2440 \mathrm{kkal} / \mathrm{kg}$ (Ruswendi, 2011), selain itu limbah kopi mengandung pektin sejumlah $6,52 \%$ (Murni dkk, 2008)

Bahan baku lainnya yang berasal dari limbah pertanian yang paling sering dimanfaatkan dalam ransum yaitu dedak padi. Dedak padi cukup disenangi ternak, meskipun ada pembatasan penggunaan dalam ransum disebabkan sifat pencahir dari dedak yang bila dipergunakan berlebihan akan menyebabkan gangguan pencernaan, kadar lemak relatif tinggi akan membuat ransum tidak tahan untuk disimpan dan adanya antinutrisi (fitat), .dedak padi rata rata mengandung $80 \%$ fitat-fosfor dari P total.

Kandungan serat kasar limbah kulit kopi sedikit lebih tinggi dibandingkan dengan dedak padi, namun dampak penggunaan setiap bahan diharapkan akan memberikan pengaruh yang positif. Atas dasar pemikiranpemikiran tersebut, maka telah dilaksanakan penelitian tentang penggunaan limbah kulit kopi sebagai salah satu bahan pakan penyusun ransum menggantikan dedak padi.
Penelitian ini telah dilaksanakan di kandang unggas Fakultas Peternakan UNSRAT Manado.Lama penelitian yaitu 6 minggu mulai tanggal 01 September 2014 hingga tanggal 12 Oktober 2014. Penelitian ini menggunakan 60 ekor ayam broiler strain CP 707, dengan umur pada saat awal percobaan memasuki umur 3 minggu.Ransum yang digunakan dalam penelitian ini terdiri 6 macam bahan jagung kuning, bungkil kelapa, tepung ikan, kedelai, dedak padi dan tepung kulit kopi. Tepung kulit kopi yang digunakan, diperoleh dari pabrik pembuat kopi bubuk yang berada di kota Kotamobagu, yang memproduksi kopi dari jenis Robusta.Komposisi Zat makanan bahan pakan penyusun ransum dapat dilihat pada tabel 1.Kandang yang digunakan yakni kandang baterai sebanyak 20 unit kandang. Setiap kandang dilengkapi dengan lampu pijar., tempat makan dan minum yang terbuat dari plastik. Perlengkapan lain yang digunakan adalah wadah pencampur ransum, timbangan, kantong plastik penampung ransum perlakuan, koran bekas, ember. Setiap unit kandang percobaan ditempatkan 3 ekor ayam broiler sebagai objek penelitian.

\section{MATERI DAN METODE PENELITIAN}


Tabel 1. Komposisi Zat-zat makanan Bahan Penyusun Ransum

\begin{tabular}{lllllll}
\hline Bahan Makanan & $\begin{array}{l}\text { Protein } \\
\%\end{array}$ & $\begin{array}{l}\text { Serat Kasar } \\
\%\end{array}$ & $\begin{array}{l}\text { Lemak } \\
\%\end{array}$ & $\begin{array}{l}\text { Energi } \\
\%\end{array}$ & $\begin{array}{l}\text { Ca } \\
\%\end{array}$ & $\begin{array}{l}\text { P } \\
\%\end{array}$ \\
\hline Jagung** & 8.5 & 22 & 3.8 & 3350 & 0.02 & 0.3 \\
Kedelai* & 37 & 5.5 & 18 & 3300 & 0.24 & 0.56 \\
B. Kelapa* & 19.2 & 14.4 & 2.1 & 1525 & 0.20 & 0.60 \\
T. Ikan* & 63.6 & 0.5 & 9.3 & 2830 & 5.81 & 3.23 \\
Kulit Kopi* & 11,18 & 21,74 & 2.5 & 2440 & 0.21 & 0.03 \\
Dedak Padi*** & 10.26 & 18.51 & 3.3 & 2400 & 0.1 & 1.3 \\
\hline
\end{tabular}

Sumber :*Hartadi, 1990., **NRC, 1994: ***Ruswendi, 2011.

Tabel 2. Komposisi Pakan Penyusun Ransum dan Zat-zat Makanan serta Energi Metabolis Ransum Percobaan

\begin{tabular}{lcccc}
\hline Bahan Pakan & R0 & R1 & R2 & R3 \\
\hline Jagung \% & 46.50 & 46.50 & 46.50 & 46.50 \\
Kedelai \% & 13 & 13 & 13 & 13 \\
Bungkil Kelapa \% & 5 & 5 & 5 & 5 \\
Tepung Ikan \% & 14 & 14 & 14 & 14 \\
Dedak Padi \% & 21 & 14 & 7 & 0 \\
Kulit Kopi \% & 0 & 7 & 14 & 21 \\
Top Mix \% & 0.5 & 0.5 & 0.5 & 0.5 \\
\hline Jumlah & 100 & 100 & 100 & 100 \\
\hline Zat-zat Makanan (\%) & & & & \\
\hline Protein \% & 21.13 & 21.20 & 21.26 & 21.33 \\
Lemak \% & 6.46 & 6.48 & 6.49 & 6.50 \\
Serat Kasar \% & 6.67 & 6.91 & 7.14 & 7.38 \\
Kalsium \% & 0.88 & 0.89 & 0.90 & 0.91 \\
Phosphor \% & 0.97 & 0.88 & 0.79 & 0.70 \\
EM (Kkal/kg) & $3064 . .73$ & 3054.02 & 3043.31 & 3032.60 \\
\hline Keterangan ${ }^{*}$ Disun
\end{tabular}

Keterangan : ${ }^{*}$ Disusun berdasarkan data tabel 2 
Penelitian ini adalah penelitian eksperimental dengan menggunakan Rancangan Acak Lengkap (Steel and Torrie, 1980) yang terdiri dari 4 perlakuan dan 5 ulangan.

$$
\begin{aligned}
\mathrm{R}_{0}= & \text { Penggantian dedak halus } 0 \%) \text { atau } \\
& \text { ransum dengan dedak padi } 21 \%+ \\
& 0 \% \text { kulit kopi } \\
\mathrm{R}_{1}= & \text { Penggantian Dedak halus }(33.33 \%) \\
& \text { atauransum dengan dedak padi } 14 \\
& \%+7 \% \text { kulit kopi } \\
\mathrm{R}_{2}= & \text { Penggantian Dedak halus }(66.66 \%) \\
& \text { atau ransum dengan dedak padi } 7 \\
& \%+14 \% \text { kulit kopi } \\
\mathrm{R}_{3}= & \text { Penggantian Dedak halus (100\%) } \\
& \text { atau ransum dengan dedak padi } 0 \\
& \%+21 \% \text { kulit kopi }
\end{aligned}
$$

Penempatan perlakuan ke setiap unit kandang dilakukan secara acak.Uji lanjut dihitung dengan menggunakan uji Beda Nyata Jujur (BNJ).

\section{HASIL DAN PEMBAHASAN}

Hasil pengamatan dan perhitungan rataan konsumsi ransum, pertambahan berat badan dan konversi ransum broiler perekor selama penelitian tertera pada tabel 3 .

\section{Pengaruh Perlakuan terhadap}

\section{Konsumsi Broiler.}

Rataan konsumsi ransum broiler pada penelitian ini berkisar antara 1782.41 - 2858.05 gram/ekor (Tabel 3). Rataan konsumsi ransum tertinggi diperoleh pada perlakuan yang menggunakan $21 \%$ dedak halus dan $0 \%$ tepung kulit kopi sedangkan terendah pada perlakuan menggunakan $0 \%$ dedak halus dan $21 \%$ tepung kulit kopi.

Hasil analisis ragam menunjukkan bahwa tingkat penggunaan tepung kulit kopi dalam ransum memberi pengaruh yang berbeda nyata $(\mathrm{P}<0.05)$ terhadap konsumsi ransum.Ini menunjukkan bahwa pemberian tepung limbah kulit kopi sampai $21 \%$ menggantikan dedak dalam ransum mempengaruhi konsumsi ransum.Hasil uji lanjut dengan uji BNJ menunjukkan bahwa semakin tinggi level penggunaan kulit kopi dalam ransum mengakibatkan semakin rendahnya tingkat konsumsi broiler. Hal ini diduga karena walaupun kandungannutrisi ransum perlakuan R0 sampai R3 ada dalam imbangan yang hampir sama namun kulit buah kopi mengandung zat anti nutrisi yaitu tannin dan kafein yang tidak palatabel bagi ternak.Anggorodi (1985) mengemukakan bahwa salah satu faktor yang mempengaruhi konsumsi ternak adalah palatabilitas ransum. 
Tabel 3. Rataan Konsumsi Ransum,Pertambahan Berat Dan Konversi Ransum Ayam Broiler perekor Selama Penelitian

\begin{tabular}{lrrrr}
\hline Parameter & \multicolumn{4}{c}{ Perlakuan } \\
\cline { 2 - 5 } & R0 & R1 & R2 & R3 \\
\hline Konsumsi (g/ek) & $2858.05^{\mathrm{a}}$ & $2581.79^{\mathrm{b}}$ & $2201.91^{\mathrm{c}}$ & $1782.41^{\mathrm{d}}$ \\
\hline Pertambahan Berat & & & & \\
Badan (g/ek) & $1236.2^{\mathrm{a}}$ & $982.33^{\mathrm{b}}$ & $834.93^{\mathrm{b}}$ & $573.13^{\mathrm{c}}$ \\
\hline Konversi Ransum & $2.32^{\mathrm{a}}$ & $2.64^{\mathrm{a}}$ & $2.66^{\mathrm{a}}$ & $3.11^{\mathrm{b}}$
\end{tabular}

Keterangan: Superskrip berbeda pada baris yang sama menunjukkan perbedaan yang nyata $(\mathrm{P}<0,05)$

\section{Pengaruh Perlakuan Terhadap Pertambahan Berat Badan}

Rataan pertambahan berat badan broiler pada penelitian ini berkisar antara $573.13-1236.2$ gram/ekor selama penelitian (Tabel 3). Rataan pertambahan berat badan tertinggi diperoleh pada perlakuan yang menggunakan $21 \%$ dedak halus dan $0 \%$ tepung kulit kopi dan terrendah pada perlakuan menggunakan $0 \%$ dedak halus dan $21 \%$ tepung kulit kopi.

Hasil analisis keragaman (Lampiran 2) menunjukkan bahwa perlakuan memberikan pengaruh berbeda sangat nyata terhadap pertambahan bobot badan.(P < 0.01).Hasil uji lanjut menggunakan uji BNJ menunjukkan bahwa semakin tinggi penggunaan kulit kopi dalam ransum mengakibatkan semakin rendahnya pertambahan bobot badan, dimana $\mathrm{R} 3$ nyata $(\mathrm{P}<0.05)$ lebih rendah dibandingkan dengan Ro, R1 dan R2 Rendahnya pertambahan berat badan pada penelitian inidisebabkan rendahnya ransum yang dikonsumsi broiler, dimana semakin rendah konsumsi menyebabkan rendahnya zat-zat makanan yang masuk dalam tubuh ternak sehingga kebutuhan untuk pertumbuhan tidak terpenuhi.Salah satu kelemahan penggunaan kulit kopi yang tidak diolah adalah kandungan tannin dan kafein (Akmal dan Filawati, 2008).

Kumar dan Singh, (1991)menyatakan bahwa tanin dapat mengikat protein membentuk ikatan kompleks protein tanin sehingga protein tersebut sukar dicerna oleh enzim protease.Tanin juga mempengaruhi metabolisme karbohidrat dengan mengikat pati sehingga sukar dicerna oleh enzim amilase yang disitasi oleh Tandi, (2010). 


\section{Pengaruh Perlakuan Terhadap}

\section{Konversi Ransum}

Rataan konversi ransum broiler pada penelitian ini berkisar antara 2.323.11(Tabel 3).Konversi ransum tertinggi diperoleh pada perlakuan yang menggunakan $21 \%$ tepung kulit kopi dan 0 $\%$ dedak halus (R3) dan terendah pada perlakuan menggunakan $0 \%$ Tepung kulit kopi dan $21 \%$ dedak halus (R0).

Hasil analisis keragaman menunjukkan bahwa perlakuan memberikan pengaruh berbeda nyata terhadap konversi ransum. Hasil uji lanjut dengan uji BNJ menunjukan semakin tinggi penambahan kulit buah kopi dalam ransum semakin tinggi pula konversi makanannya, walaupun tidak ada perbedaan antara R0, R1 dan R2. Semakin tingginya konversi ransum menunjukkan bahwa broiler semakin tidak mampu untuk menggunakan ransum yang dikonsumsi secaramaksimal.Angka konversi yang semakin tinggi diduga karena komposisi dari kandungan serat kasar kulit kopi yang terdiri dari lignin, pektin dan selulosa selain itu kandungan zat antinutrisi dalam kulit buah kopi yakni tannin dan kafein juga ikut berperan dalam menghambat pemanfaatan ransum yang dikonsumsi secara maksimal.Menurut Tillman (1984) bahwa unggas tidak mampu mencerna serat kasar karena tidak memiliki enzim pencerna serat kasar. Serat kasar yang masuk dalam saluran pencernaan akan mempercepat laju perjalanan makanan sehingga zat-zat makanan yang terkandung dalam ransum tidak dapat dicerna secara maksimal. Menurut Anggorodi (1979) faktor yang mempengaruhi konversi makanan antara lain suhu, laju perjalanan makanan melalui alat pencernaan, bentuk fisik dari bahan makanan dan komposisi makanan.

\section{KESIMPULAN}

Berdasarkan nilai konversi ransum hasil penelitian ini dapat disimpulkan bahwa tepung kulit kopi dapat menggantikan dedak halus sampai $66.66 \%$ atau penggunaannya sebesar $14 \%$ dalam ransum broiler.

\section{DAFTAR PUSTAKA}

Akmal dan Filawati, 2008. Pemanfaatan Kapang Aspergillus nigersebagai Inokulan Fermentasi Kulit Kopi dengan Media Cair dan Pengaruhnya Terhadap Performans Ayam Broiler. Jurnal Ilmiah Ilmu-Ilmu PeternakanAgustus, 2008, Vol. XI. No.3.

Anonimous, 2010. Komposisi Dedak dan Bungkil.http://komunitashobiiskeli nci.wordpress.com/2010/05/14/ko mposisi-dedak-dan-bungkil 
Anggorodi, R.1985. Kemajuan Mutakhir Ilmu Makanan Ternak Unggas. Cetakan Pertama. Universitas Indonesia Press, Jakarta.

Anggorodi.R. 1979. Ilmu Makanan Ternak Umum. PT. Gramedia, Jakarta.

Diniyah, N., Maryanto., A.Nafi., D.Sulistia., A. Subagio. 2013. Ekstraksi dan Karakterisasi Polisakarida Larut Air dari Kulit Kopi Varietas Rabika (coffea arabica) dan Robusta (coffea canephora), Jurnal Teknologi Pertanian Vol. 14 No. 2 [Agustus 2013] 73-78.

Hartadi, H., S. Reksohadiprodjo., A.D. Tillman, 1990. Tabel Komposisi Pakan Untuk Indonesia. Universitas Gadjah Mada, Press

Kumar, R. And M. Singh. 1991. Tannins, their adverse role in ruminant nutrition. J. Agric.Food Chem. 32: $447-453$.

Murni,R.Suparjo,dkk. 2008. Buku Ajar Teknologi Pemanfaatan Limbah Untuk Pakan. Laboratorium Makanan Ternak Fakultas Peternakan Universitas Jambi.

National Research Council. 1994. Nutrient Requirements of Poultry. 9th. Ed. National Academy Press.Washington D.C, New York

Raudah1 dan Ernawati, 2012. Pemanfaatan Kulit Kopi Arabika dari Proses pulping Untuk Pembuatan Bioethanol, Jurnal Reaksi (Journal of Science and Technology). Jurusan Teknik Kimia Politeknik Negeri Lhokseumawe. Vol. 10 no.21, Juni 2012 ISSN 1693-248x12.
Ruswendi, 2011. Teknologi Pakan Berkualitas untuk Sapi Potong. Balai Pengkajian Teknologi Pertanian Bengkulu.

Steel, R.G.D. and J.H. Torrie. 1980. Principles and Procedure of Statistics

Tandi, E. J. 2010. Pengaruh Tanin Terhadap Aktivitas Enzim Protease. Seminar Nasional Teknologi Peternakan dan Veteriner.Makasar

Tillman, A.D., Hartadi., S. Reksohadiprojo dan S. Prawirokusumo. 1984. Ilmi Makanan Ternak Dasar. Gadja Mada University Press. Yogyakarta. 